HARRIET TUBMAN 



\section{HARRIET TUBMAN}

MYTH, MEMORY, AND HISTORY

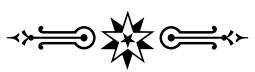

Milton C. Sernett

DUKE UNIVERSITY PRESS

DURHAM AND LONDON

2007 
(C) 2007 Duke University Press

All rights reserved

Printed in the United States

of America on acid-free paper @

Designed by Amy Ruth Buchanan

Typeset in Janson by

Tseng Information Systems, Inc.

Library of Congress Cataloging-in-

Publication Data appear on the

last printed page of this book.

Generous support for this publication was provided by SYRACUSE UNIVERSITY through THE DEPARTMENT OF AFRICAN AMERICAN STUDIES in THE COLLEGE OF ARTS AND SCIENCES.

Production of this work was also made possible through the assistance of

THE MARY DUKE BIDDLE FOUNDATION. 
To

AMANDA MAY HEACOCK,

our first grandchild,

born September 29, 2004

"Hold to that Bright Shining Star!"

橉 
